
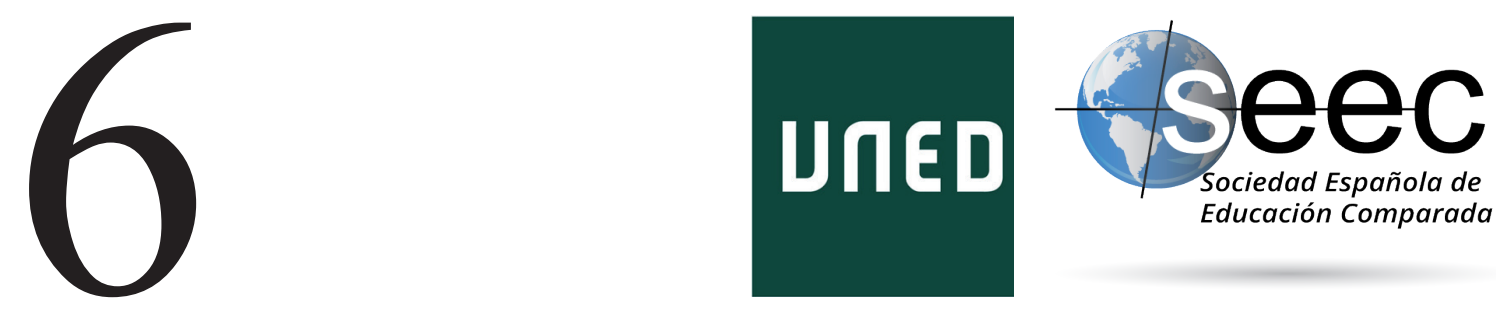

\title{
Changing patterns of imperialism and education: the United Kingdom*
}

\author{
Cambiando los patrones del imperialismo \\ y la educación: el Reino Unido
}

\section{Leslie Bash**}

DOI: 10.5944/reec.31.2018.21590

\section{Recibido: 12 de marzo de 2018 Aceptado: 9 de mayo de 2018}

\footnotetext{
* Acknowledgement: I wish to express my gratitude to Bob Cowen for his incisive and valuable comments during the completion of this article. Needless to say, I take full responsibility for its content.

**LESLIE BASH holds an Honorary Readership at the UCL Institute of Education, University College London where he is Director of the International Centre for Intercultural Studies. In addition, he is also Reader in Jewish Education at Leo Baeck College, London, and is currently vice-president of the International Association for Intercultural Education. He was previously based at Anglia Ruskin University where he was Principal Lecturer in Education and director of the Doctorate in Education programme. Having graduated in sociology and having obtained a teaching certificate he subsequently taught social studies in London secondary schools and, at the same time pursued postgraduate studies in education, eventually gaining a $\mathrm{PhD}$ in comparative education. He has published widely, having authored, co-authored, edited and contributed to a number of volumes, as well as journal articles, in urban, international and intercultural education. Among his research interests are religion, the state and education; diversity, equity and education; intersectionality and cultural issues in education. Datos de contacto: E-mail: L.Bash@ucl.ac.uk
} 


\begin{abstract}
Education has been central to the maintenance of modern empires. Educational policies and practices under British imperialism reflected the complexities, tensions and conflicts in the different territories of the Empire. This is illustrated with specific reference to inter-war Palestine and Imperial India where education policy sometimes had unintended consequences in divided societies. Cultural imperialism was an inherent aspect of colonial education with curricular implications for schooling in the United Kingdom. As the British Empire underwent change and eventually declined, education also changed in response. However, the change was not linear, with the legacy of empire continuing both in the former colonial territories and in the UK itself up to present times, with implications both for the formal and informal dimensions of learning. Importantly, the English language is maintained, in different forms, as a continuing symbol of empire, together with diverse and sometimes complex responses at a time when interculturalism, postcolonialism, and globalisation have affected the discourse on the British Empire. At the same time, the discourse is sometimes complicated by an apparent resurgence of imperial sentiment while the arts continue to reflect critical attitudes towards past imperial power. The article concludes with the view that the development of a critical understanding of the relationship between education and empire is necessary to ensure changes in pedagogy with regard to greater inclusion of those with histories of marginalisation and subordination.
\end{abstract}

Key Words: empire; imperialism; education; power; hegemony; culture

\title{
Resumen
}

La educación ha sido fundamental para el mantenimiento de los imperios modernos. Las políticas y prácticas educativas bajo el imperialismo británico reflejaron las complejidades, tensiones y conflictos en los diferentes territorios del Imperio. Esto se ilustra con referencias específicas a la Palestina entre guerras y la India Imperial, donde la política educativa a veces tuvo consecuencias imprevistas en sociedades divididas. El imperialismo cultural era un aspecto inherente de la educación colonial con implicaciones curriculares para la escolarización en el Reino Unido. A medida que el Imperio británico sufrió cambios y, finalmente, se redujo, la educación también cambió en respuesta. Sin embargo, el cambio no fue lineal, ya que el legado del imperio continuó tanto en los antiguos territorios coloniales como en el Reino Unido hasta el presente, con implicaciones tanto para las dimensiones formales como informales del aprendizaje. Es importante destacar que el idioma Inglés se mantiene, en diferentes formas, como un símbolo continuo del imperio, junto con respuestas diversas y, a veces complejas en un momento en que la interculturalidad, el post-colonialismo y la globalización han afectado el discurso sobre el Imperio Británico. Al mismo tiempo, el discurso se complica a veces por un aparente resurgimiento del sentimiento imperial mientras que las artes siguen reflejando actitudes críticas hacia el poder imperial del pasado. El artículo concluye con la opinión de que es necesario desarrollar una comprensión crítica de la relación entre educación e imperio para garantizar cambios en la pedagogía con respecto a una mayor inclusión de aquellos con historias de marginación y subordinación.

Palabras clave: imperio; imperialismo; educación; poder; hegemonía; cultura 


\section{Introduction}

This article explores the relationships between empire and education in the United Kingdom, where the nature of both empire and education have undergone significant change. The article is not concerned with British imperialism as such but rather its decline. In addition, the article does not claim to be comprehensive in its treatment of the topic. For example, the Church of England as a quasi-imperialist agency in education, both domestically and in the British Empire at large, remains unexamined. Furthermore, the article does not aim to engage with detailed arguments about the alleged benefits or otherwise brought by British imperialism to its colonial territories. Clive Whitehead (2006), for example, undertook a historiographical study of British imperial education in relation to India and concludes that many of the commentaries written contemporaneously and in later years have either been misunderstood or are heavily ideological in orientation. Consequently, such detailed analyses are better left to future historians to battle it out.

The central purpose of this article is to extend our comparative and intercultural understandings of the relationship between the increasingly globalised realm of education and aspects of past and current forms of imperialism, specifically in the context of the British 'Empire'. There are some preliminary observations of the centrality of education to empires, as conventionally defined. Secondly, there is an attempt to demonstrate that the development of the British Empire had significant implications for domestic education policy-making and implementation. However, it will also be argued that the tensions and contradictions which are endemic in education policies and practices in the domestic context are exacerbated in colonial rule. To illustrate this, attention is drawn to the examples of imperial India and the inter-war Palestine British Mandate. Additionally, there is an attempt to show that education policy and practice during the colonial era helped to shape not only the realities of empire but also the conceptualisations of empire as these underwent change at home. Finally, it will be argued that British imperialism, even in an alleged post-colonial era, continues to be expressed in specific cultural forms refracted through formal and non-formal educational processes and institutions. As manifestations of globalised change and interpenetration they also reflect the legacies associated with the educational presence of the British. The article concludes with some observations of the possible direction of educational change in an era of neoimperialism (the economic domination of poorer nations by wealthier nations), interimperial exchange and interpenetration, and globalisation.

\section{Education and empires: initial observations}

Empires require serious commitment, efficient administration and effective defence. As Adam Smith $(1976,830)$ observed, all empires have proved mortal, while aiming at immortality, doubtless echoing Aristotle who is said to have noted that the fate of empires depended on the education of its youth (Haselhurst, 2012). Thus, any consideration of the relationship between empires and education demands an examination of structures, institutions and processes in overlapping spheres of public life. As far as the British Empire is concerned attention is inevitably drawn, inter alia, to the historic operations of bodies such as the East India Company, the functions of an elite schooling system and the role of missionary Christianity. This, however, is to confine the focus to the Empire 
as it impacted upon the overseas territories which it governed, whereas it is equally important to focus on the British Empire as it was experienced domestically. Moreover, an adequate examination of education and the British Empire must take account of the non-formal dimension and the 'hidden curriculum' of imperialist socialisation.

Beyond the specific imperialism of Britain, a study of the relationship between empires and education demands attention, not least because of a built-in assumption regarding transnational power relations. Power imbalance ensures a transmission of a mix of language, knowledge, ideas, and cultural forms reflecting imperial priorities. Clearly, empires have not been generally transnational associations of equals, neither have they been designed for dispensing largesse.

In the latter half of the twentieth century much of this was encapsulated in the notion of cultural imperialism. Notably, Martin Carnoy (1974) provides the now classic text which claimed that since colonialism was about domination and subordination it follows that colonial education policy must reflect this through epistemic domination of the colonised. The argument was not so much that imperialism exported metropolitan education systems and processes to the colonised, but that education exported imperialism, both at home and abroad. In a nutshell, colonial education explicitly and deliberately operated to overshadow or even eclipse the existing knowledge(s) of colonised peoples.

Carnoy's approach echoes the ideas of the still fashionable Antonio Gramsci (1971, 1977) who, in the early part of the $20^{\text {th }}$ century, famously promoted the idea of hegemony. For Gramsci, a writer and activist in the Marxist tradition, hegemony provided an explanation for the maintenance of power on the part of a ruling class, essentially through a process of ideological penetration of the entire society with the consequence that the working class were absorbed into the very fabric of capitalism. This was, of course, later reinforced by the now somewhat unfashionable Louis Althusser (1977) with his 'structuralist' view of education as an ideological state apparatus which apparently could not be defeated. This contrasted with the more positive approach of Gramsci, a noted commentator on education, who was sufficiently Marxist, in the political sense, to seek a means by which the young could attain the critical consciousness needed for radical societal change. Thus, he sought to provide a curricular basis for countering hegemonic processes in what he saw as a revolutionary war of attrition. Possibly counter-intuitively, such a curriculum would be grounded in 'the classics' aimed at all, rather than the elite, and would enable the young to counter both the 'false consciousness' engendered by capitalism and the 'folklore' of peasant society and the lumpen proletariat.

The extent to which Gramsci's theories connect with those of writers on imperialism and, specifically, Carnoy's view of education, may be questioned. Both Gramsci and Carnoy emphasise ideological power in a general sense but the domestic setting differs from an imperial setting. A geographically dispersed empire characterised by diverse nationalities, ethnicities, religions and languages tests the hegemonic processes of the 'mother country' in the way that it does not need to do in the domestic context. Moreover, the sub-polities and economies of empires inevitably contribute to a large degree of relative autonomy as, in the case of the British example, in countries as varied as India, Uganda and Southern Rhodesia (FOTW, 2015). To take the argument a little further, compared with the domestic education authorities, it was probable that a much more difficult task was faced by colonial authorities in their attempt to exercise hegemony in the British imperial territories. 


\section{Education in empire: the British example}

In the case of the British Empire, the colonised territories of Africa, Asia, Australasia and the Caribbean occupy the popular imagination. However, a focus on lands which are far from the imperial hub serves to emphasise a distinction between a perceived, superior collective self, the UK, and numerous inferior others - the 'colonials', this distinction is reinforced when language, religion, ethnicity and racialised differences are considered.

Closer to home, Ireland provides an arena for contestation in which there are highly polarised politicised positions over whether Ireland was, and continues to be, an imperial object. Pointedly, this politically contested situation in Ireland has played itself out educationally in separate school systems and in separate curricula (Citizens Information, 2013; Department of Education, 2018). Until partition in 1921, the 'United Kingdom of Great Britain and Ireland' was an indication of the non-imperial status of Ireland, it was officially part of 'metropolitan' Britain (just as Algeria was considered part of metropolitan France until independence). After all, Ireland was not generally considered to be distinct linguistically (Irish Gaelic having been marginalised in practice as a minority language for some years) nor characterised by 'differences in race'. Moreover, in ethnic and broader cultural terms, Ireland and Britain were seen to be historically intertwined. Yet, past and ongoing politics have dictated two broadly distinct narratives - unionism and nationalism - which reflect orientations towards metropolitan and colonised views respectively. Additionally, nationalist ideology correlates more or less with Catholic identification; unionism with various shades of Protestantism. While the the partition of Ireland approximates geo-politically with a republican/unionist division this is by no means absolute in the case of the north with the presence of a significant minority with republican sympathies. Leaving aside the decades of conflict, a lasting educational consequence of the republican/unionist division is the perpetuation of myths (Bash, 2001) about British imperialism and the danger posed to the union with the United Kingdom. Insofar as freedom from colonialism is an ongoing issue for nationalists in Northern Ireland the history taught in Catholic schools unsurprisingly reflects the mythology of a once independent united country.

Gary McCulloch has made some succinct observations in relation to the power and influence of the English public schools, citing the importance of 'character' and the playing field in the consolidation of empire in its 'furthest outposts' (McCulloch, 2009, 170). Politically; cultural imperialism, in its heyday, did not carry with it the negative connotation of imposition which it acquired more latterly with late twentieth century post-colonial thinking. Undoubtedly, in Britain, it was perceived as a good thing and contrasted with a less than favourable view of the way in which other empires had conducted themselves in relation to their colonial 'subjects'. In the post-war period, the British were enjoined to have a sense of pride in their cultural legacy as increasing numbers of imperial territories gained further autonomy if not independence. The British could therefore take a condescending view of a country such as Belgium which had abandoned its duty as colonial master towards the Congo (later, Zaire), with catastrophic political consequences (Hochschild, 1999). This is somewhat akin to a good parent with the colonies, having been successfully educated in the British manner, eventually being trusted to leave the nest and become self-reliant. The then UK prime minister, Harold Macmillan, famously opined in 1960 that 'the winds of change' were blowing throughout Africa and it was the responsibility of others not to hinder such change. Even in 1949 there appeared to be 
some awareness among British senior servants, as Whitehead notes $(2005,316)$ in an anonymous observation:

"[...] all that one culture can ever do, when in contact with others, is to act as missionary for its own beliefs [...] Africa will take what it wants, digest it slowly, and assimilate what it does not spit out again"

The process of the dismantling of the British Empire gained momentum with the partition of India into two separate independent states in 1947 and accelerated in the late 1950 s and 1960s. Alongside this process ran a growing anti-colonial narrative, eventually becoming the political and academic conventional wisdom in the UK in the late twentieth century. Yet, the $21^{\text {st }}$ century is in the process of witnessing challenges to liberal, postcolonial complacency with a renaissance of views considered by many to have perished long ago. On this occasion it is the rehabilitation of the British Empire which has gained support among some politicians and an odd historian or two. Here, British imperialism has become the focus of attention among those who consider its apparent virtues may have been overshadowed by a prolonged negative press during the latter half of the $20^{\text {th }}$ century (Olusoga, 2016; Owen, 2016). More than that, Shashi Tharoor (2016: 184) speaks of the fashion for what might be termed retro-imperialism, expressed stylistically in ......

"[...] such delights as a burger called the Old Colonial, a London bar named The Plantation and an Oxford cocktail [...] named Colonial Comeback [...]"

Indeed, a noted rehabilitator of the British Empire's reputation, Niall Ferguson, has sought to reinforce the view of Britain's position of imperial moral superiority through a less than rosy opinion of other empire builders who...

"[...] were little more than pirates, exploiting resources for their own end while seeking to impose their culture and religion on the local inhabitants." Ferguson (2003, n.d.)

Perhaps, though, Ferguson might have been advised to have taken note of an earlier observation of William Joynson-Hicks, UK Home Secretary, in 1928:

"I know it is said in missionary meetings that we conquered India to raise the level of the Indians. That is cant. We conquered India as an outlet for the goods of Britain. We conquered India by the sword, and by the sword we shall hold it." (Quoted in: Tharoor, 2017, 174)

The debate among scholars over the reassessment of the British Empire has arisen at the same time as protests over whether established physical monuments to such imperialist and notorious - figures as Cecil Rhodes should be dismantled (Chaudhuri, 2016). It might be reckoned that the Rhodes statue is especially germane to education as a result of Rhodes' connection with the University of Oxford. More broadly, the issue of 'whose history?' appears to be at the very heart of how imperialism is interpreted in relation to education at all levels. Until the latter half of the $2 \mathrm{O}^{\text {th }}$ century it was generally taken for granted that - British - imperialist perspectives on history were the sole perspectives. The idea that there were alternative historical narratives which reflected the experiences and memories of the colonial 'subjects' took some time to reach the school curriculum whether in Britain or in the former imperial possessions. The notion that history was a contested arena was alien to those who had sat at the feet of the classic scholars in the mould of a Macaulay or a Trevelyan. 
However, it is important to note that British imperialist perspectives continue to impact upon the popular imagination. Indeed, by 2018, a general mood appears to have resurfaced throughout Europe (and across the Atlantic) characterised at the very least by a nostalgia for the national, if not imperial, glories of yesteryear. This nostalgia was clothed in the garments of resurgent European nationalisms and separatisms as well as the populism of the maverick winner of the 2016 US presidential election. Most importantly for Britain was the outcome of the referendum to leave the European Union (Brexit). While cinema at this time ('Dunkirk' and 'Darkest Hour') patriotically choreographed the evacuation of British troops from northern France in 1940 and Winston Churchill's internal cabinet coup of the same year, the prevailing underlying wistfulness reflected in Brexit was arguably imperial rather than national. Brexit, according to one commentator (Younge, 2018), evoked empire, a world (almost literally, given its size) lost, indeed sacrificed on the altar of Europhilia. Brexit, however, could assist in its resurrection through opening the door to past colonial connections and renewed trade agreements. Grandeur was no delusion - it characterised exactly who the British were and where they were: big, strong and at the centre of the world.

A central question concerns the extent to which the imperial past of the early $21^{\text {st }}$ century, mediated through the British collective imagination, connected with the realities of empire and their contemporaneous cultural and educational manifestations. At a time when the school populations of Britain were, 'ethnically', of Anglo-Saxon or Celtic heritage there was little to challenge the implicit supremacist position of the United Kingdom at the head of the largest empire the world had known. The residue of the British Empire lingered in the British collective subconscious long after most of it had disappeared. The school atlases of the 1950 os pictured a world still bathed in pinkish red and geography textbooks stereotyped the 'natives' of the colonised lands (Tomlinson and Dorling, 2016, 4), even if they were now part of a sanitised ex-empire called the British Commonwealth of Nations (later to be transformed simply to 'The Commonwealth'). Slavery was barely mentioned, except insofar as its abolition together with the abolition of the slave trade, was a source of pride, much in the same way that early $19^{\text {th }}$ century factories and mines legislation was treated in school textbooks as evidence of the Victorian liberal conscience.

The 'White Dominions' took pride of place even though they had long begun to tread a path away from the 'mother country', looking southwards in the case of Canada, and northwards in the case of Australasia (Commonwealth of Australia (2001). At the same time, India was pictured rather differently - as it were, an empire within an empire.

Arguably, the British Empire, despite its idealised pretensions as the successor to Rome, evolved as a complex, somewhat pragmatic affair. Until the 1960 s all the inhabitants of the British Empire (and the successor British Commonwealth) were treated as quasi-citizens - subjects - of the United Kingdom which carried immigration and settlement rights (differing from the Roman Empire where citizenship was a prized reward for imperial services). The politico-legal status of colonial territories was by no means uniform: some were categorised as straightforward colonies, others were protectorates, still others were 'protected states'. In the $2 \mathrm{O}^{\text {th }}$ century, other territories were governed under League of Nations mandates (Palestine) or as United Nations trusteeships (Tanganyika - later, with Zanzibar, Tanzania). This diversity of colonial statuses apparently denoted differences in relationship with the various subject territories and their inhabitants, as well as historical background, giving rise to varying degrees of political autonomy within an overall framework of colonial rule. 
Hence, the Empire ought to be relied upon to maintain and enhance British cultural hegemony in the face of apparent unenlightened backwardness. This might overestimate the strength of imperial rule insofar as colonised peoples were entirely under the direct control of the colonisers. However, the British Empire was a complex entity and its approach to education in the various territories under its domination illustrated this through the contradictions and tensions associated with the diversity of imperialist aims and objectives. Exploitation, subordination and subjugation dwelt alongside colonization, Christian evangelism, orientalism and much else. Hence it is important to disentangle the goals of British imperialism, insofar as they impacted upon educational policies implemented in the now former UK colonial territories -and continue as legacies.

Walter Rodney (1972, 264-5, 281), a classic standard bearer for neo-Marxist perspectives on British imperialism is predictably vehement in his view that colonial education was designed to subjugate and exploit the colonised in the interests of the ruling class. With specific reference to Africa, and unrelated to the intentions of teachers in the colonial schools, he observed that the machinery of empire was relentless in its manner of operation and its grand objectives. Samir Amin (1975), in concurring with Rodney, adds that colonial education, unsurprisingly, also had the expressed function of training a cadre to manage the Empire at the local level.

It is not necessary to identify with neo-Marxist arguments to agree with the view that British imperialist education policy had an exploitative edge to it. It was a view readily accepted by the East India Company and successive British governments. Rather, the relationship between the United Kingdom and its colonial territories constituted a quid pro quo. As far as the educational missionary activities of Christian evangelists in the British Empire are concerned much has been documented see, for example: Holmes, 1967). For the purposes of this article there is a useful overview provided by Gascoigne (2008, p.159) who notes that...

"[...] Empires need creeds to sustain their expansionist energies and provide them with a justification for domination [...]."

Unlike many other empires the British experience of educational missionary activities was far from straightforward and ultimately was not one of an absolute identification of church with state. Protestant missionary work reflected denominational diversity and was frequently infused with objectives apparently derived more from Old Testament aims of exploiting the earth's resources than the explicit otherworldly objectives of, for example, Jesuitical Spanish imperialism. More significantly, for the post-colonial era, the educational work of the mission schools paradoxically helped to limit the impact of cultural imperialism. As Gascoigne (2008, p.174) further observes, in noting that missionaries acted, mostly unintentionally, as 'gravediggers' of empire since they:

"[...] provided the education that made it possible for the colonised to argue back with the colonisers and, in many cases, some of the ideas which helped shape notions of independence [...]"

Some of these unintentional consequences of colonial policies are seen in the experiences of the colonial authorities in their attempts to manage education in territories characterised by deep divisions. Accordingly, the next section considers some of these aspects in two quite different colonial settings. 


\section{The Palestine Mandate and Imperial India}

In the case of the British Empire, it is difficult to achieve a satisfactory grasp of the colonial educational politics in complex, divided societies. To state it differently such an understanding is achieved only if it is realised that the classically debated diverse and contested aims of education were grafted onto little understood social, cultural and political contexts.

One core issue in relation to education policy is whether the British Empire was in large part a case of 'divide and rule' or, somewhat caustically, 'divide and misrule'. With this in mind we now turn to two quite different regions where British imperialism made its presence felt, in the midst of division and conflict. The first is pre-independence India, while the second is inter-war Palestine. India perhaps epitomised this more than any other imperial possession while Palestine, following the 1917 Balfour Declaration, provided an arena for an ultimately less than successful League of Nations mandate granted to Britain.

Education policy under the Palestine Mandate was conditioned by a number of factors: the imperial legacy of the Ottomans, the existing educational institutions of the 'indigenous' communities, the missionary activities of various Christian denominations, the pursuits and interventions of external religious and Zionist Jewish organisations, together with the imperialist ambitions of the British. This last conditioning factor, of course, must be viewed against the backcloth of the post-World War I settlement, the Sykes-Picot plan for the 'carve-up' of the Middle East between France and the UK, and the control of oil.

Accordingly, in the context of the Palestine Mandate, the tensions and dynamics surrounding empire and education are manifested in this complex society. The educational ambitions of the largely Muslim Arab population in the main reflected a conscious wish to 'de-Ottomanise' in the pursuit of an ill-defined nationalism. The rapid replacement of Turkish with Arabic as the medium of instruction, together with religious revivalism, was acceptable to the British colonial administration insofar as the Arabs could be secured in a relatively low hierarchical position. On the other hand, it was clear that the British had helped to ignite a pan-Arab nationalist flame, as suggested by Khadurri (1970, 23):

"The study of the Arabic language and literature in recent times revived awareness of the 'past glories'... and the Arabs began to take pride in the role their ancestors had played in the establishment of the Islamic empire. This 'historical memory', a blend of fact and vivid imagination, became an important ingredient in Arab nationalism, since it created, in the minds of young men a sense of compelling duty to restore these glories to their people."

However, this re-awakening failed to shape itself in the way Zionism had done, not least because its modality of resistance failed on the whole to take an educational form which was underpinned by well-established civil society institutions. The latter is of interest since they had their origins more broadly in Europe and North America rather than in Britain in particular. Importantly, these institutions established educational modalities in Palestine rooted in the modernistic practices. For traditionalists, such practices might be viewed as a combination of secularism and cultural imperialism. 
By contrast, Arab nationalism in Palestine, as observed by Wolf $(1981,286)$ :

"[...] was not in a comparable position to the Zionist movement to effect society's transition to modernity or the course of education. Its social and political vision and the mechanism to implement its objectives had not yet matured [...]"

This was further underlined by Renton (2010, n.d.), noting that:

\begin{abstract}
"the Arab population suffered from under-development, debt, widespread illiteracy, disillusionment, and the after effects of Britain's decimation of the Palestinian Uprising of 1936 to 1939. These seeds of Zionist victory and Palestinian defeat were the direct outcome of Britain's drafting, interpretation, and implementation of the League of Nations mandate for Palestine."
\end{abstract}

These observations reinforce a general view that Britain was content to preside over a divided population served by highly differentiated school systems. Significantly, these systems have survived to the present time and, leaving aside the West Bank, are experienced in Israel on a daily basis. The vast majority of the Arab citizens of Israel (comprising twenty percent of the entire population) are Muslim with the majority of the children attending state-funded Arabic-medium schools. While this is not the place to enter a full discussion of education in present-day Israel one curricular aspect, a legacy of colonial rule, is worth noting: the place of the English language. For Jewish Israeli children, at the second level of schooling, English is studied as a second language, after Hebrew as the first language. Arabic, if studied at all, constitutes a third language. For Arab Israeli children, English is studied as a third language, after Arabic as the first and Hebrew as the second. One specific manifestation of this is that Arab secondary school children underachieve in English at the matriculation examination (Bagrut) compared with the children in Jewish schools (Zaher, 2012).

At the very least, education in Israel indirectly reflects the legacy of British colonial rule. While there are overt and covert narratives in Israel which place much of the blame for the continuing Israeli-Palestinian conflict on British imperialism in the region it should be noted that institutional and curricular patterns in Israeli education reflect its legacy. Indeed, despite the perceived incursion of American cultural imperialism throughout Israeli society, education is but one institutional sector which has been influenced by, if not inherited, from the Mandate era. Specifically, the parliamentary and judicial systems stand out (notwithstanding proportional representation which has ensured permanent coalition government). The English language, although ubiquitous, is perhaps largely an intercultural phenomenon, reflecting North American, South African, and other Englishspeaking country influences.

Likewise, the UK presided over an Indian Empire characterised by deep historical divisions: religious, cultural, linguistic, socio-economic. Such divisions were the product of changes over millennia - wars, migrations, colonisation - and constituted a significant challenge for British imperialism. The caste system presented a situation of societal complexity little understood by colonial masters in addition to the religious tensions between Hinduism and Islam. An alternative view to that of the British viewing India as an issue of imperial tension management, is that of Will Durant writing in 1930, cited by Shashi Tharoor $(2016,1)$ : 
"The British conquest of India was the invasion and destruction of a high civilization by a trading company [the British East India Company] utterly without scruple or principle, careless of art and greedy of gain, over-running with fire and sword, a country temporarily disordered and helpless, bribing and murdering, annexing and stealing, and beginning that career of illegal and 'legal' plunder which has now gone on ruthlessly for one hundred and seventy-three years."

With the benefit of hindsight, and peering through the lens of postcolonialism, there is some astonishment at the effrontery with which British imperialist educational narratives successfully challenged 'indigenous' knowledge systems. There is little space here to recount the illustrious history of education in India in detail but even a cursory glance serves to highlight the misplaced arrogance of imperial rule. Rural indigenous pedagogies in the $18^{\text {th }}$ and $19^{\text {th }}$ century frequently emphasised the social character of learning and the use of memory in the process of solving problems relevant to village life, often cutting across caste divisions (Jha, 2011, 119-137). Imperialist education policies, on the other hand, tended towards liberal individualism with the consequence that divisions were exacerbated, a process that was entirely functional to the maintenance of the Raj. At the same time, Tharoor (2016: 183) observes that the British left India in 1947 with low levels of literacy (16 per cent in general and 8 per cent for females) characterising the population.

It is not altogether surprising that Tharoor is fairly unambiguous in his view that British imperial education policy in India had 'very little to commend itself' (ibid.184). He further cites the existence of traditional Indian higher education institutions which had international student populations, and which pre-dated the hallowed spires of Oxford and Cambridge by some centuries. As with early European universities, Indian higher education was, as Max Weber had noted, bound up with religious life and the priestly orders.

And yet, the emphasis upon the primacy of 'indigenous' education carries with it what many would see as the dangers of orientalism. Following the work of Edward Said (1978), in simplified terms the latter has come to denote what are now perceived as patronising views and actions in relation to colonised peoples and territories on the part of diverse Western scholars and artists. Whitehead (2005), in referencing imperial India, observes that orientalists saw themselves as sincere defenders and promoters of local cultures and knowledge systems, structures and world views. Thus,

"[...] they championed the study of Sanscrit, Persian, Hindi and other indigenous languages and sought to minimize the impact of Western civilization on everyday Indian life."

Finally, Tharoor himself notes that despite the cultural imperialism implied by the ubiquity of the English language he has chosen to use that language in his own writing (a point discussed in more general terms later in the article). 


\section{The empire in education: historical and contemporary perspectives}

At the same time, there is the rather obvious point that the British Empire had a considerable impact on the social, political, economic - and educational - fabric of the UK itself. This was manifested in diverse ways and at diverse levels, both consciously and unconsciously, which continue to wield influence in the twenty-first century.

In this section it will be argued that the continuing significance of the British empire in contemporary British educational narratives is closely related to past and current debates about 'British values'. As previously pointed out, the English elite 'public school system explicitly functioned to prepare the future leaders of the Empire. At the same time, the hidden curriculum of the public schools extolled those values which were to provide the underpinning for an imperialist consciousness and which, in turn, would permeate the entire fabric of British education. Accordingly, it has been claimed that educational ethnocentrism had its origins in classical elite schooling in Britain oriented towards the preservation and enhancement of the Empire:

"Public school headteachers were able to spread their imperial cultural values via their overt and hidden curriculum; sermons, prize day speeches, school magazine editorials all provided means of reinforcing these values [...] [which] percolated from the public schools to other schools [...] [comprising] elements of nationalism, militarism and racial arrogance [...]" (Tomlinson, 1989, 30-31)

Times have apparently changed; the British Empire has all but vanished, but questions remain with regard to the enduring presence of nationalism, militarism and racial arrogance. In the closing decades of the $20^{\text {th }}$ century and the early $21^{\text {st }}$ century the residue of the Empire has continued to give rise to cultural flashbacks, including the Falklands Campaign of 1982 and the recurring tensions involving Gibraltar and Spain (with the added frisson provided by Brexit). However, it is with the officially sanctioned focus on the requirement that schools place an emphasis on 'British values' that our attention is drawn to the significance of the place of the United Kingdom among the world's nationstates (Department for Education, 2014). We suggest here that there is an implicit uniqueness ascribed to 'British Values' and that it harks back to a half-remembered past of imperial glory when Great Britain bestowed a set of principles to guide the lives of those who were fortunate enough to be born as subjects of the Empire. Our view here is that there is a hidden neo-imperialist attitude that such values as fairness, democracy, the rule of Law and the English language were priceless gifts barely known to the rest of the world. While this view may smack a little of hyperbole it should be recalled that recent UK government policy has sought to temper the importance of the more universal discourse of human rights (Judd, 2013).

This leads ineluctably to the question of identity. The beginning of the $20^{\text {th }}$ century saw the hidden, and even the overt, curriculum of schools in the UK devoted to the inculcation and reinforcement of a collective identity that was at heart imperial in character. The Boer Wars and the First World War were the loci of patriotism and the need to defend the Empire. At around the same time Empire Day had been instituted with enthusiastic 
support from the UK parliament, with Viscount Milner (Hansard, 2016, 604) observing that:

"[...] Empire Day .... has become to all the scattered communities of the British race the symbol of that unity of feeling which possesses them all with a common loyalty to one Sovereign and one Flag [...]",

Furthermore,

.......[In 1914] Empire Day was observed ........in the United Kingdom [where] it was kept last year in 25,666 schools with an average attendance of just over 5,000,000.

On the other hand, there was some awareness of resistance to the institution of Empire Day. As Milner observed,

"That figure is good, but the comparison is not altogether favourable to the United Kingdom, where there exists in certain quarters what I can only describe as a sort of hostility to the Flag which one is obliged to regard as a sort of psychological curiosity. That hostility is based on an idea-I cannot imagine whence derived-that the Flag, the Union Jack, is a symbol of militarism. It is not militarism which the Flag symbolises but patriotism, a very different matter. Militarism may be good or bad, according to the meaning ... attached to that much-abused word; but there can be no doubt that patriotism, love of country, sense of duty, is an unmixed good [...]" (ibid).

Central to our argument is the observation that the British Empire incorporated goals which, in a variety of settings, were: the pursuit of political-economic gain, the maintenance and reinforcement of social and cultural hierarchies, and the amelioration of perceived cultural deficits. At times, these goals were pursued simultaneously, but by no means given equal weight. Unsurprisingly, this diversity of goals gave rise to tensions and conflicts, especially in those territories seen to be characterised by problematic inter-communal relations - which were probably the majority. Thus, British imperialism required the implementation of a balancing act which frequently resulted in seemingly incompatible promises being made to diverse communities.

At this point we would highlight the relevance of post-colonialism to the discussion, Much as the definition of empire has posed problems for historians and other commentators so does post-colonialism. Given that an 'ism' is involved, we argue that the latter references an ideological stance, however vague, rather than an era which follows the end of colonial rule. In the case of Britain, whose empire has not entirely vanished (e.g., the Falklands and Gibraltar) post-colonialism can exist alongside imperial remnants, especially in a discussion of education. Thus, in its most direct form, post-colonialism privileges resistance to the continuation of the penetration of empire.

In response, the not unreasonable question arises as to the place of post-colonialism in the school curriculum. Haydn (2014) has noted that following the inception of the National Curriculum in English schools in 1991 the study of the British Empire was assured, although it appeared to be firmly rooted in the past alongside the Roman Empire. However, history teachers did begin to encourage classroom discussion about 'the extent to which the British Empire was a force for good or otherwise'. On the other hand, Haydn also observes the subsequent tendency for English politicians to encourage a celebratory 
view of the Empire, linking it with the propagation of 'British Values'. Indeed, at the time of writing (March 2018), the death of Roger Bannister, the first athlete to run a mile in under four minutes (1954), was announced. The symbolism of this, together with the events of the previous year (the coronation of the Queen of the UK and the climbing of Mount Everest) underlined the glory that was (is?) the British Empire. These events continued to occupy a significant place in hidden curriculum for years to some.

More widely, both in the UK and in its former colonial territories, a key question concerns the extent to which the British Empire was maintained through educational and quasi-educational processes and institutions. Social and cultural reproduction theories might suggest that is indeed what happened and that the legacy remains today. We therefore argue, in general terms, that long after the demise of the British Empire degrees of psychological, social and cultural imperialism survive political imperialism. Indeed, we would expect this to be the case where imperial rule was historically devolved to local administrators, missionaries, private companies and other non-governmental bodies. (Brock [1982] has exemplified aspects of the legacy of colonial education in the Caribbean)

More than ever, conventional educational institutions - schools, colleges and universities - are not able to claim a monopoly over the processes of teaching and learning. The non-formal conduits of information and knowledge transmission increasingly threaten to eclipse the formal, whether in the traditional context of artistic and cultural institutions such as museums and art galleries, or in the context of the internet and 'social media'. Images of empire are inevitably perpetuated in a variety of settings and refracted in ways which are not always immediately discernible.

On the other hand, an institution such as the British Museum has been traditionally seen as one of the most important emblems of imperial status and over time has attracted generations of children, mostly accompanied by adults and frequently as members of school parties. The Elgin Marbles exhibit at the British Museum previously symbolised the power of British imperialism to define the world order while, today, their re-naming as the Parthenon Sculptures possibly indicates a retreat from this symbolism. No doubt this was an outcome of Greece's persistent voicing of its intense displeasure at what they perceive as the theft of its artefacts (further reinforced by the deliberate gaps left in the parallel sculptures exhibit in the Acropolis Museum in Athens).

As a counterweight to the continuing didacticism of a now diluted British imperialism the Tate Britain gallery in London mounted an exhibition, Artist and Empire, in 2015-2016. Opening a review of the exhibition, Jonathan Jones (2015) observed:

"The British Empire has become invisible. It is an abstraction that people argue about. Right and left lay claim to its pride or shame, but the historical entity - whose rights and wrongs patriots and radicals now debate - lies cold in its grave, its banners, medals, statues and pith helmets neglected and ignored."

However, this exhibition sought "to resurrect the British Empire as a physical reality" and engage people through a sophisticated process of curating.

Overarching technological and institutional dimensions are the changing demographics of British society and changing cultural and normative assumptions. It can no longer be taken for granted that the British-born descendants of those who were colonial subjects will view the Empire in quite the same way that previous generations had done. 
Post-colonial perspectives on empire have long since entered curricular discourse and have made their way into the public arena of entertainment and the arts. One example has been the BBC television series which came on stream in March 2018 which focused on civilisations, a reference back to a series from forty years previously, Civilisation. The latter was arguably a vehicle for a linear approach to cultural history channelled through the lens of imperial Anglocentrism, while the new series posited a world of culturally diverse peoples and polities which had interacted over time and space.

At a more general level, there have been attempts to counter the kind of collectively inherited views of one such as Macaulay $(1835,10)$, who infamously uttered that ".... a single shelf of a good European library was worth the whole native literature of India and Arabia....". In recent times, exhibitions curated in London museums and art galleries have placed the Empire in perspective in demonstrating that the cultural products of those who have been colonised do not constitute a separate realm from that of the 'civilised' imperial nation. Indeed, in the case of the British Empire, scholars in the field of intercultural education such as Jagdish Gundara (1999) have focused on the process of cultural interpenetration and its positive implications for art education in UK schools. Here, it is argued that the marginalisation of subordinated cultures rooted in regions colonised by Britain impacts negatively on children and young people whose heritages lie in those regions.

Arguably, the single most important cultural factor in the empire-education nexus in the case of Britain is the English language. The obvious point to make here is that there is a commonly held assumption that the English language is the unique property of the United Kingdom, if not England, which has been bestowed as an imperial gift upon the colonies. The schools and other educational institutions situated in the colonial territories had the major task of imparting the language to those who were confined to tongues perceived to be of little or no value outside the realm of the local. More than that, English was seen to possess cultural - if not spiritual - superiority, and thus bring its possessor that much nearer to salvation. More prosaically, English was a two-edged sword: although its proponents sought to subordinate, even eliminate, 'indigenous' languages, it was adopted and adapted to meet the needs of the colonised populations. With the passage of time not only has English ceased to be the sole property of the English/British it has also morphed into several linguistic forms with discrete characteristics. These linguistic forms or dialects reflect intercultural hybridity, giving rise to distinct modalities of dialogical interaction and distinct literatures.

We can leave aside the classic English-speaking example of the United States which, of course, dispensed with its colonial status over two hundred years ago, although the current position of English is increasingly challenged by that of Spanish. However, the question remains as to the extent to which British imperial influence persists through the global dominance of the English language, a crucial question for many educationists. While 'indigenous' languages have had strong support from such bodies as UNESCO the pressure to acquire and to use English has been keenly felt. Possibly, this has enabled the English/British to maintain an imagined sense of their collective identity which for many has been bolstered in recent years by a retreat from the potentially more universal, secularised proposed solutions to societal problems. 


\section{Conclusion}

The relationship between the British Empire and education is complex and contradictory. Debates among historians continue over the many aspects of the British imperial machinery and their implications for educational processes and institutions in the colonised territories. The debates differ according to whether the focus is the direct involvement of the British state, or whether the focus is the indirect involvement through non-governmental organisations, commercial agencies and religious organisations. All such debates are paralleled by a more general consideration of cultural imperialism and hegemony, especially in the context of arguments which suggest that the British Empire continues to exist in the collective diverse imagination.

The processes of globalisation and rapid technological change have additionally shaped the educational consequences of the British post-Empire era with the interpenetration of diverse cultural and economic imperialisms. The legacy of the British Empire is more difficult to detect amidst the intercultural mix and the dynamics of the global economy which impact upon formal and non-formal educational processes and institutional structures. It might be judged that the central educational issue regarding the past and present British Empire concerns ownership. Comparative and intercultural studies in education enjoin us to engage with ownership since the teaching of history together with the hidden curriculum both of schools and other educational institutions - and with the hidden curriculum of the media - tends to be interpreted in a nationally-oriented manner. Too often, 'national' has denoted 'imperial', excluding those who do not see themselves as possessing ownership of the national/imperial narrative. A younger generation, increasingly with experiences and inherited stories of colonialism, foreignness and marginalisation, may be instrumental in helping to shift to a more balanced and critical understanding of the nexus between education and the British Empire.

\section{References}

Althusser, L. (1977). For Marx. London: New Left Books

Amin, S. (1975). What education for what development? Prospects, 1.

Bash, L. (2001). Siege cultures and the mythology of nationhood: the implications for the maturation of education systems. Intercultural Education, 12(a), 5-11.

Brock, C. (1982). The Legacy of Colonialism in West Indian Education. In K. Watson (Ed.), Education in the Third World (pp.119-140). Abingdon/New York: Routledge

Carnoy, M. (1974). Education as Cultural Imperialism. New York: Longman

Chaudhuri, A. (2016, March 16). The real meaning of Rhodes must fall. The Guardian. Retrieved from https://www.theguardian.com/uk-news/2016/mar/16/the-realmeaning-of-rhodes-must-fall

Citizens Information Board (2013). Overview of the Irish education system. Retrieved from http://www.citizensinformation.ie/en/education/the_irish_education_ system/overview_of_the_irish_education_system.html 
Commonwealth of Australia (2001). Strengthening Australia-Japan Economic Relations. A report prepared by Professor Gordon de Brouwer (Australian National University) and Dr Tony Warren (Network Economics Consulting Group) for the Department of Foreign Affairs and Trade. Commonwealth of Australia. Retrieved from https://web.archive.org/web/20110315085555/http://www.dfat.gov.au/ geo/japan/aus_relations/ser_report.pdf

Department for Education (2018). Retrieved from https://www.education-ni.gov.uk/

Department for Education (2014, November 27). Guidance on promoting British values in schools published. Strengthened guidance on improving the spiritual, moral, social and cultural development of pupils. Retrieved from https://www.gov.uk/ government/news/guidance-on-promoting-british-values-in-schools-published

Ferguson, N. (2003, January 25). 'Empire: How Britain Made the Modern World by Niall Ferguson.' The Guardian. Retrieved from https://www.theguardian.com/ books/2003/jan/25/digestedread

FOTW. (2015). British Empire and Overseas Territories. Retrieved from https://www. fotw.info/flags/gb-colon.html\#list

Gascoigne, J. (2008). Introduction: Religion and Empire an Historiographical Perspective. Journal of Religious History, 32 (June).

Gramsci, A. (1971). Selections from Prison Notebooks. (Q. Hoare Q \& G. Nowell-Smith, Eds.) London: Lawrence \& Wisehart.

Gramsci, A. (1977). Selections from Political Writings, 1910-1920. London: Lawrence \& Wisehart.

Gundara, J. \& Fyfe, C. (1999). Intercultural visual literacy and art history. In R. Mason \& D. Boughton (Eds.), Beyond Multicultural Art Education (pp. 87-102). New York: Waxmann Verlag

Hansard. (1916, April 5), 21, 604-22. Retrieved from http://hansard.millbanksystems. com/lords/1916/apr/o5/empire-day

Haydn T (2014). How and what should we teach about the British Empire in English schools?

In J. Wojdon (Ed.) Handbook of the International Society of History Didactics: Colonialism, decolonization and post-colonial historical perspectives - challenges for history didactics and history teaching in a globalizing world (pp. 23-40). Schwalbach: Wochenschau Verlag.

Haselhurst, G (2012). Philosophy of Education- Introduction. Retrieved from http:// www.spaceandmotion.com/Philosophy-Education.htm

Hochschild, A. (1999). King Leopold's Ghost: A Story of Greed, Terror, and Heroism in Colonial Africa. Harcourt: Houghton Mifflin. 
Holmes, B. (Ed.) (1967). Education Policy and the Mission Schools. London: Routledge.

Jha, H. (2011, June). Decay of Village Community and the Decline of Vernacular Education in Bihar and Bengal in the Colonial Era. Indian Historical Review, 119137 .

Jones, J. (2015, November 23). Artist and Empire review - a captivating look at the colonial times we still live in. The Guardian. Retrieved from https://www. theguardian.com/artanddesign/2015/nov/23/artist-and-empire-review-tatebritain

Judd, T. (2013, March 4). Conservatives promise to scrap Human Rights Act after next election. The Independent. Retrieved from http://www.independent.co.uk/ news/uk/politics/a-betrayal-of-british-values-tories-accused-of-damaging-uk-sreputation-on-human-rights-851850o.html

Khadurri, M. (1970). Political Trends in the Arab World. Baltimore: Johns Hopkins.

Macaulay, T. (1835) From: H. Sharp (Ed.), Bureau of Education. Selections from Educational Records, Part I (1781-1839) (pp. 107-117). Calcutta: Superintendent, Government Printing, 1920. Reprint. Delhi: National Archives of India, 1965.

Olusoga, D. (2016, January 23). Wake up, Britain. Should the empire really be a source of pride? The Guardian. Retrieved from https://www.theguardian.com/ commentisfree/2016/jan/23/britain-empire-pride-poll

Owen, J. (2016, January 22). British Empire: Students should be taught colonialism 'not all good', say historians. The Independent. Retrieved from http://www. independent.co.uk/news/education/education-news/british-empire-studentsshould-be-taught-colonialism-not-all-good-say-historians-a6828266.html

Renton, J. (2010, March 19). Forgotten lessons: Palestine and the British Empire. Open Security. Retrieved from https://www.opendemocracy.net/opensecurity/jamesrenton/forgotten-lessons-palestine-and-british-empire

Rodney, W. (1972). How Europe Underdeveloped Africa. London: Bogle L'Ouverture Publications.

Said, E. (1978). Orientalism. New York: Pantheon.

Smith, A. (1976). An Inquiry into the Nature and Causes of the Wealth of Nations. Indianapolis: Oxford University Press.

Tomlinson, S. (1989). The Origins of the Ethnocentric Curriculum. In G. Verma (Ed.), Education for All: a landmark in pluralism (pp. 26-41). Lewes: Falmer Press

Tomlinson, S. \& Dorling, D. (2016) Brexit has its roots in the British Empire - so how do we explain it to the young? Staggers, The New Statesman Blog, (p.4). Retrieved from http://www.dannydorling.org/wp-content/files/dannydorling_publication_ id5405.pdf 
Whitehead, C. (2005). The historiography of British imperial education policy, Part I: India. History of Education, 34(3), 315-329.

Wolf, J. (1981). Selected aspects public education in the development of Palestine 19201946. (Unpublished doctoral dissertation.) Boston College Graduate School of Arts and Sciences, Boston, MA.

Younge, G. (2018, February 3). Britain's imperial fantasies have given us Brexit. The Guardian 3 February. Retrieved from https://www.theguardian.com/ commentisfree/2018/feb/o3/imperial-fantasies-brexit-theresa-may

Zaher, R. (2012). Democracy in the Israeli Education System: The Case of the English Matriculation Exam. Intercultural Education, 23(6), 527-540. 